\title{
Analisis Numerik Penyerapan Energi pada Sabot untuk Pengujian Bird Strike
}

\author{
Riskha Agustianingsih ${ }^{*} \cdot 1$, Sahril Afandi ${ }^{2}$, Rizky Fitriansyah ${ }^{3}$, Agus Bayu $^{4}$, Endah Yuniarti ${ }^{5}$ \\ ${ }^{1,2,5}$ Prodi Teknik Penerbangan, Fakultas Teknologi Kedirgantaraan, Universitas Suryadarma \\ ${ }^{3,4}$ Pusat Teknologi Penerbangan Lembaga Penerbangan dan Antariksa Nasional \\ "Corrresponding Author: ikaikariskha@gmail.com
}

\begin{abstract}
Abstrak - Pengujian Bird Strike dilakukan menggunakan alat SHPB (Split Hopkinson Pressure Bar) yang menembakkan sabot (wadah burung). Pada ujung alat SHPB, sabot akan dihentikan oleh stopper sehingga burung akan terlepas dan meluncur dengan bebas hingga mengalami tumbukan dengan komponen uji. Sabot harus memaksimalkan kecepatan burung ketika keluar (terlepas dari sabot). Berdasarkan persamaan impuls dan momentum, hal ini dapat diperoleh dengan meminimalkan waktu tumbukan sehingga gaya impulsnya akan meningkat. Tujuan penelitian ini adalah mengetahui waktu tumbukan, pola grafik Energy Absorption (EA), Peak Crushing Force (PCF), dan Mean Crushing Force (MCF). Dari parameter tersebut, maka diperoleh sabot yang diinginkan berdasarkan waktu tumbukan tersingkat, PCF dan MCF tertinggi, serta EA terendah. Simulasi dilakukan menggunakan perangkat lunak elemen hingga (Abaqus CAE) berdasarkan variasi material (AA6061-T6, S355, dan AISI 1340) sabot. Berdasarkan hasil dan pembahasan, diperoleh bahwa waktu tumbukan paling singkat dimiliki variasi material AISI 1340 dengan nilai $0.00071 \mathrm{~s}$. EA terendah untuk variasi material dimiliki oleh AISI 1340, yaitu sebesar $2.51 \mathrm{~kJ}$. PCF tertinggi untuk variasi material dimiliki oleh material AISI 1340, yaitu $466 \mathrm{kN}$. Ditentukan bahwa berdasarkan nilai waktu (t) paling singkat, PCF, MCF paling tinggi, dan EA paling rendah, maka diperoleh material AISI 1340 sebagai material yang diinginkan karena paling berpengaruh terhadap peningkatan kecepatan burung setelah keluar dari sabot.
\end{abstract}

Kata Kunci: Bird Strike, Sabot, Energy Absorber, Impact, AA6061-T6, S355, AISI 1340.

Abstract - Bird Strike testing is carried out using a SHPB (Split Hopkinson Pressure Bar) tool that fires sabot (bird containers). At the end of the SHPB tool, the sabot will be stopped by the stopper so that the bird will be released and glide freely until it collides with the test component. Sabot must maximize the speed of the bird when it comes out (apart from sabot). Based on the impulse and momentum equation, this can be obtained by minimizing the collision time so that the impulse force will increase. The purpose of this study was to determine the collision time, graphic patterns of Energy Absorption (EA), Peak Crushing Force (PCF), and Mean Crushing Force (MCF). From these parameters, the desired sabotage is obtained based on the shortest collision time, highest PCF and MCF, and lowest EA. Simulations were carried out using finite element software (Abaqus CAE) based on material variations (AA6061-T6, S355, and AISI 1340) sabot. Based on the results and discussion, it was found that the shortest collision time possessed AISI 1340 material variations with a value of $0.00071 \mathrm{~s}$. The lowest EA for material variation is owned by AISI 1340, which is $2.51 \mathrm{~kJ}$. The highest PCF for material variation is owned by AISI 1340 material, which is $466 \mathrm{kN}$. It was determined that based on the shortest time value (t), the highest PCF, MCF, and lowest EA, the AISI 1340 material was obtained as the desired material because it most affected the increase in bird speed after exiting the sabot.

Keywords: Bird Strike, Sabot, Energy Absorber, Impact, AA6061-T6, S355, AISI 1340. 


\section{PENDAHULUAN}

Bird strike adalah tabrakan antara hewan terbang dan kendaraan yang umumnya terjadi pada pesawat. Berdasarkan laporan dari Federal Aviation Administration (FAA), terhitung dari tahun 2015 sampai 2019 telah terjadi bird strike lebih dari 60.663 pada pesawat komersial. Bird strike sering terjadi pada ketinggian di bawah 3.000 kaki dengan persentase lebih dari $95 \%$ yang mengakibatkan kerusakan besar sehingga fase penerbangan lepas landas (take-off), pendakian (climb), pendekatan (approach), dan pendaratan (landing) menjadi fase $\mathrm{kritis}^{[1]}$.

Fenomena ini masih menjadi salah satu penyebab dari kerusakan komponen pesawat. Untuk memperhitungkan kerusakan tersebut, maka diperlukan pengujian bird strike yang bertujuan mengetahui kekuatan suatu komponen. Pengujian ini mensimulasikan fenomena bird strike yang dialami suatu komponen ketika beroperasi dalam penerbangan.

Pengujian bird strike dilakukan menggunakan alat yang dikenal dengan istilah Split Hopkinson Pressure Bar (SHPB) (lihat Gambar 1.2). Peran alat ini adalah untuk meluncurkan burung yang diletakkan pada wadah silinder tipis (dikenal dengan istilah sabot yang ditampilkan pada Gambar 1.1) sebelum akhirnya meluncur ke komponen uji. Sabot diletakkan pada pipa panjang yang kemudian diberikan tekanan sehingga mampu meluncur dengan kecepatan tertentu. Pada ujung pipa, sabot akan dihentikan oleh stopper sehingga burung akan terlepas dan meluncur dengan bebas hingga mengalami tumbukan dengan komponen uji. Akibat dari penghentian oleh stopper, sabot akan mengalami deformasi berupa progressive buckling.

Sabot harus memaksimalkan kecepatan burung ketika keluar (terlepas dari sabot). Berdasarkan persamaan impuls dan momentum, hal ini dapat diperoleh dengan meminimalkan waktu tumbukan sehingga gaya impulsnya akan meningkat. Menurut hipotesis, waktu tumbukan yang minimal dapat diperoleh apabila deformasi (progressive buckling) dari sabot memiliki nilai rendah. Tinggi dan rendahnya proses deformasi disebabkan oleh beberapa faktor, di antaranya material yang digunakan dan kecepatan tumbukan (antara sabot dan stopper).

Keterkaitan penelitian ini dengan pesawat terbang adalah untuk memaksimalkan penggunaan alat SHPB yang digunakan dalam pengujian bird strike. Maksud dari memaksimalkan adalah ketika diperoleh kecepatan burung yang lebih tinggi dari pengujian sebelumnya. Harapannya dengan tekanan yang sama, maka dapat diperoleh peningkatan kecepatan luncur pada burung setelah sabot mengalami tumbukan dengan stopper (burung lepas dari sabot). Dengan kata lain, ketika tekanan yang digunakan untuk menghasilkan kecepatan yang sama lebih kecil, maka dapat diperoleh efisiensi penggunaan tekanan dari alat SHPB.

Berdasarkan Civil Aviation Safety Regulation (CASR), alat ini harus mampu meluncurkan burung bermassa 2, 4, dan 8 pon. CASR juga mengatur kecepatan yang dimiliki burung ketika tumbukan dengan komponen uji, yaitu sama dengan kecepatan maksimum approach (CASR 23) dari suatu pesawat ${ }^{[11]}$.

Eksperimen merupakan metode terbaik untuk menganalisis kasus pada penelitian ini. Namun, metode ini kurang efektif (tidak dapat memberikan hasil yang berulang karena perbedaan geometri sabot dari manufaktur) dan efisien (perlu waktu dan biaya dalam proses manufaktur). Oleh karena itu, penelitian ini menggunakan metode numerik untuk mengatasi kekurangan dari metode eksperimen. Namun, eksperimen tetap diperlukan untuk melakukan validasi metode numerik.

Pada penelitian ini, simulasi tumbukan antara sabot dan stopper dilakukan untuk memperoleh waktu deformasi terkecil dari variasi material (didukung oleh variabel-variabel penyerapan energi) dan membuktikan efek waktu terhadap penyerapan energi. Simulasi dilakukan menggunakan perangkat lunak elemen hingga Abaqus. Abaqus adalah salah satu aplikasi yang secara luas digunakan untuk melakukan proses desain, analisis, dan optimasi. Untuk penelitian impak, Abaqus mampu memberikan kemudahan dalam memahami mekanisme deformasi dan respon struktur penyerap energi ketika menerima beban impak. 


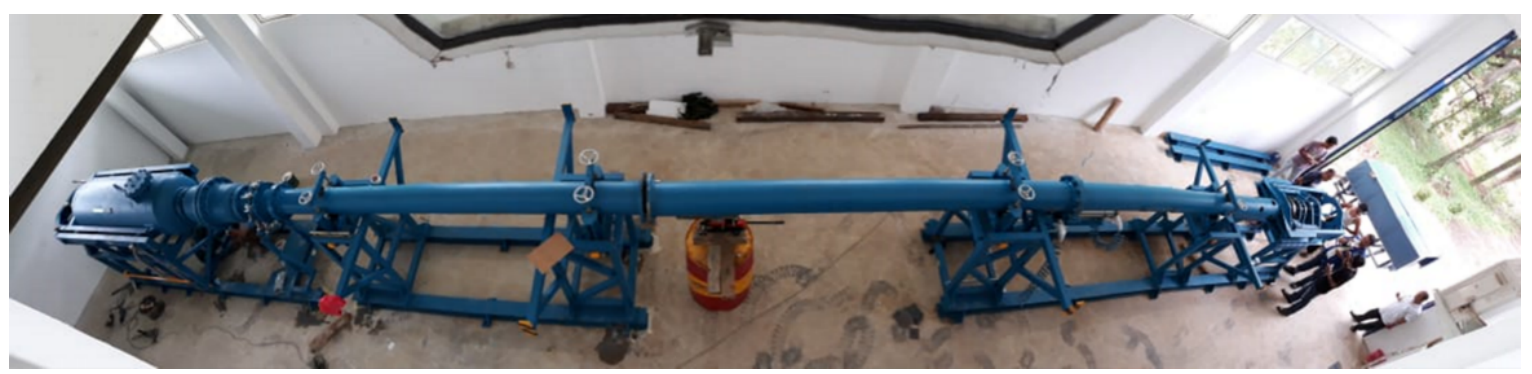

Gambar 1.1 Alat SHPB milik PUSTEKBANG LAPAN

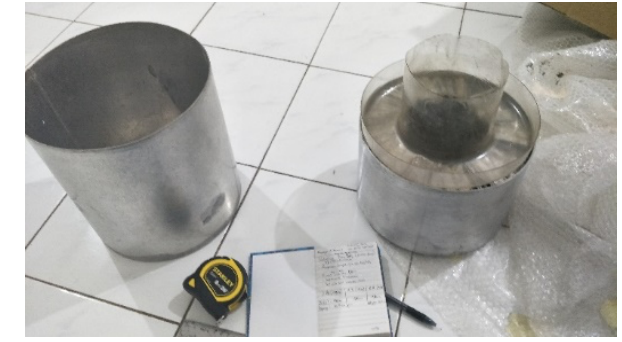

Gambar 1.2 Sabot sebagai wadah burung milik PUSTEKBANG LAPAN

\section{METODE PENELITIAN}

2.1 Parameter Indikator

Beberapa parameter indikator untuk penyerapan energi adalah sebagai berikut:

- Energy Absorption, EA Adapun perhitungan untuk mengetahui nilai energi yang diserap pada suatu struktur, yaitu dengan mengintegralkan area dibawah kurva force vs displacement yang dirumuskan pada persamaan sebagai berikut:

$$
E A(d)=\int_{0}^{d} F(x) d x
$$

$F(x)$ adalah instantaneous force dan (x) adalah deformasi yang terjadi pada struktur.

- Peak Crushing Force, PCF

Peak Crushing Force adalah gaya penghancur maksimum yang dialami oleh benda selama mengalami beban aksial. Gaya ini biasanya terjadi pada awal tumbukan untuk mengakibatkan struktur engalami buckling.

- Mean Crushing Force, MCF

Mean Crushing Force biasa disebut gaya penghancur rata-rata yang dapat dirumuskan sebagai berikut:

$$
\mathrm{MCF}=\frac{\mathrm{E}_{\mathrm{A}}}{x_{\max }}
$$

Gaya rata-rata dapat dihitung dengan membagi penyerapan energi terhadap jarak deformasi maksimum struktur.

\subsection{Geometri}

Geometri pada sabot untuk simulasi untuk penampangnya berbentuk lingkaran memiliki diameter luar $25 \mathrm{~cm}$ dan diameter dalam $13 \mathrm{~cm}$ seperti pada Gambar 2.1 dengan ketinggian $84 \mathrm{~mm}$ dan tebal 1.1 $\mathrm{mm}$ seperti pada Gambar 2.2. Ruang antara diameter luar dan diameter dalam diisi dengan filler/pengisi yaitu berbentuk lembaran honeycomb.

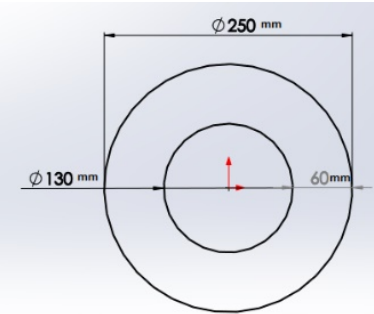

Gambar 2.1 Dimensi sabot

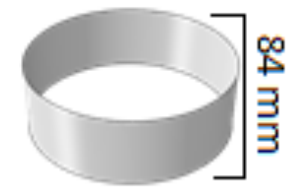

Gambar 2.2 Sabot pemodelan numerik dengan ketinggian $84 \mathrm{~mm}$

Lembaran honeycomb merupakan filler / pengisi sabot yang berfungsi untuk menahan burung (lihat Gambar 2.3). Lembaran ini memiliki ukuran sel $4.8 \mathrm{~mm}$ dengan ketebalan sel $0.0051 \mathrm{~mm}$.

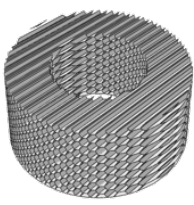

Gambar 2.3 Honeycomb pemodelan numerik dengan tinggi sabot $84 \mathrm{~mm}$

Stopper berfungsi sebagai target dari sabot yang ditembakkan oleh alat SHPB 
dengan berisikan burung. Stopper ini memiliki bentuk persegi dengan ukuran seperti panjang $0.3 \mathrm{~m}$ dan lebar $0.3 \mathrm{~m}$.

Tabel 2.1 Properti Mekanik Materia|[2],[3],[4]

\begin{tabular}{ccccc}
\hline Material & $\begin{array}{c}\text { Massa Jenis } \\
\left(\mathbf{k g} / \mathbf{m}^{\mathbf{3}}\right)\end{array}$ & $\begin{array}{c}\text { Modulus Young } \\
(\mathbf{G P a})\end{array}$ & $\begin{array}{c}\text { Yield Stress } \\
(\mathbf{M P a})\end{array}$ & Poisson Ratio \\
\hline AA 6061-T6 & 2700 & 68.28 & 337.687 & 0.3 \\
St 355 & 7800 & 210 & 355 & 0.3 \\
AISI 1340 & 7800 & 200 & 434 & 0.29 \\
\hline
\end{tabular}

Tabel 2.2 Properti Mekanik Material Aramid Ox-core 4.8-48[5]

\begin{tabular}{cccccccccc}
\hline $\begin{array}{c}\text { Massa } \\
\text { Jenis } \\
\left(\mathbf{k g} / \mathbf{m}^{3}\right)\end{array}$ & $\mathbf{V}_{12}$ & $\mathbf{V}_{13}$ & $\mathbf{V}_{\mathbf{2 3}}$ & $\begin{array}{c}\mathrm{E}_{1} \\
(\mathrm{MPa})\end{array}$ & $\begin{array}{c}\mathrm{E}_{2} \\
(\mathrm{MPa})\end{array}$ & $\begin{array}{c}\mathrm{E}_{3} \\
(\mathrm{MPa})\end{array}$ & $\begin{array}{c}\mathbf{G}_{12} \\
(\mathrm{MPa})\end{array}$ & $\begin{array}{c}\mathbf{G}_{13} \\
(\mathrm{MPa})\end{array}$ & $\begin{array}{c}\mathbf{G}_{23} \\
(\mathrm{MPa})\end{array}$ \\
\hline 48 & 0.2606 & 0.2240 & 0.0219 & 128.7 & 12.6 & 229.8 & 1.6 & 42.4 & 25 \\
\hline
\end{tabular}

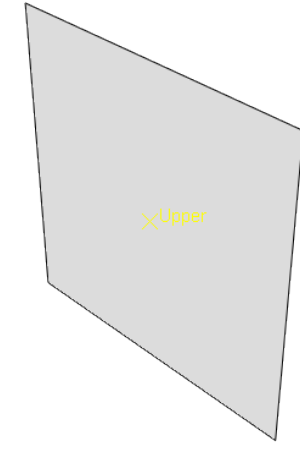

Gambar 2.4 Pemodelan numerik stopper

\subsection{Properti Material}

Material tabung adalah Alumunium Alloy 6061-T6, Steel 355, dan AISI 1340. Properti mekanik ketiga material tersebut ditampilkan pada Tabel 2.1. Selain itu, properti mekanik dari material yang digunakan untuk filler / pengisi (lembaran honeycomb), yaitu Aramid Ox Core 4.8-48 ditampilkan pada Tabel 2.2.

\subsection{Assembly}

Setiap part yang terdapat pada Subbab 2.1 dilakukan penggabungan hingga menjadi kesatuan seperti pada Gambar 2.5. Part tersebut adalah tabung, honeycomb, dan stopper.

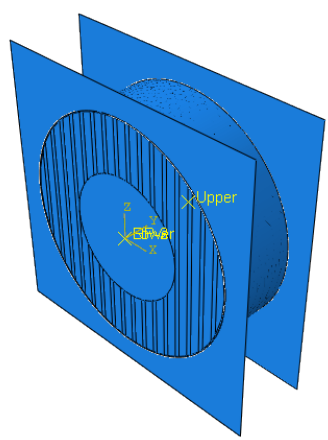

Gambar 2.5 Assembly Sabot

\subsection{Step}

Waktu simulasi memiliki nilai $0.003 \mathrm{~s}$. Waktu tersebut dipertimbangkan karena model sabot telah mengalami deformasi secara keseluruhan akibat tumbukan yang terjadi. Jumlah frame yang dihasilkan sebanyak 300 dengan interval waktu sebesar $1 \times 10^{-5} \mathrm{~s}$.

\subsection{Interaksi}

Tipe kontak yang digunakan adalah General contact karena mewakili keseluruhan model untuk dianalisis. Selanjutnya, digunakan kefisien gesekan dengan nilai 0.2. Selain itu, digunakan juga interaksi constraint tie pada alas sabot yang ditunjukkan dengan simbol lingkaran berwarna kuning pada Gambar 2.6. 


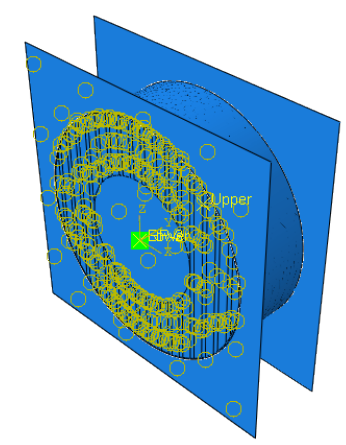

Gambar 2.6 Interaksi pada Sabot

\subsection{Pembebanan dan Kondisi Batas}

Kecepatan merupakan pembebanan yang diaplikasikan pada sabot dengan kecepatan $62 \mathrm{~m} / \mathrm{s}$ (CASR 23.775). Adapun kondisi batas (Boundary Condition) pada setup, yaitu diaplikasikan pada stopper seperti ditampilkan Gambar 2.7 berjenis fixed (menahan pergerakan sumbu translasi dan rotasi).

Tabel 2.3 Setup Meshing

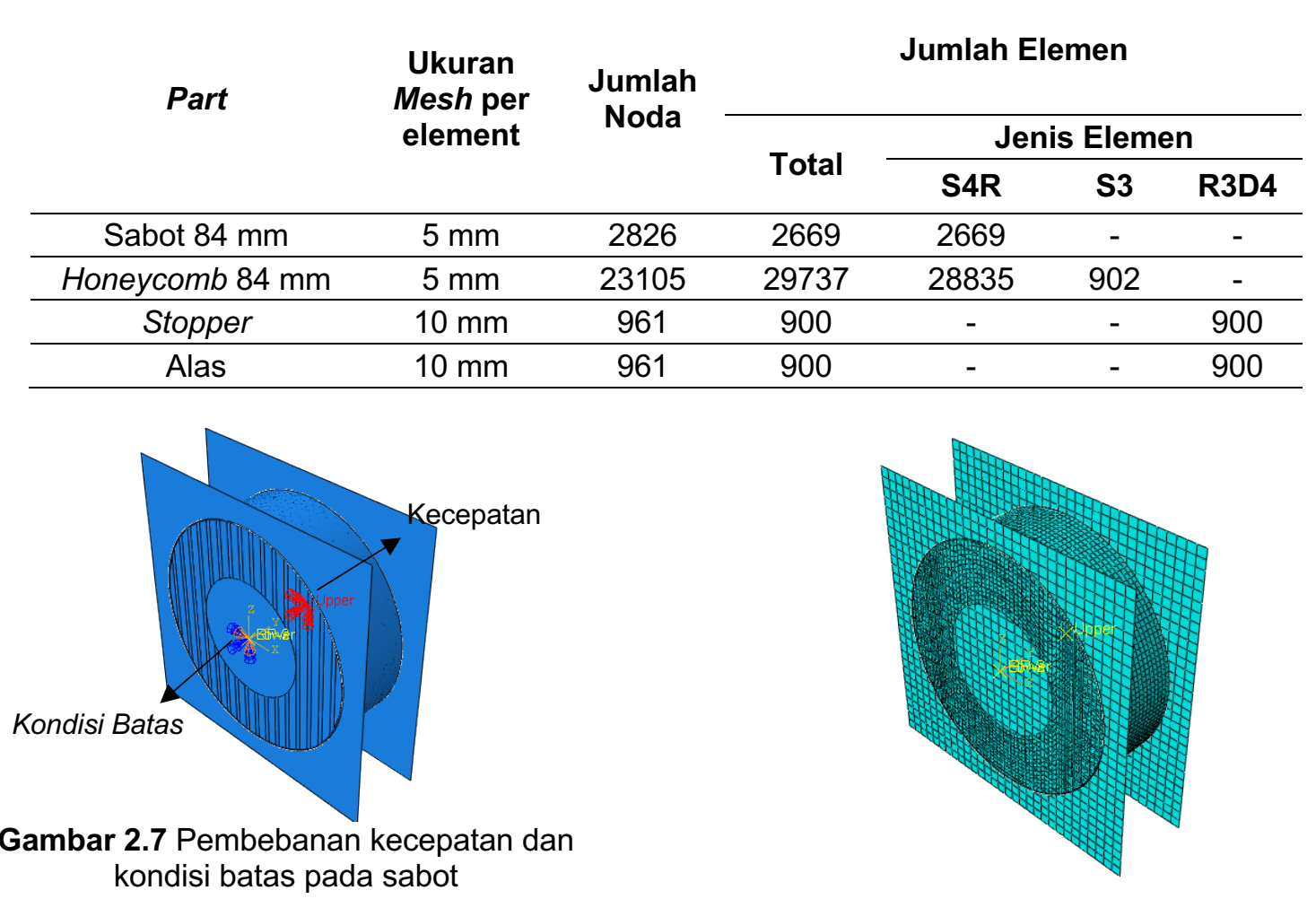

Gambar 2.8 Mesh pada sabot

\subsection{Mesh}

Ukuran mesh per elemen, jumlah noda, jumlah dan jenis elemen ditampilkan pada Tabel 2.5. Masing-masing part yang telah di-meshing ditampilkan pada Gambar 2.8.

\subsection{Data Keluaran (Output)}

Variabel keluaran pada penelitian ini berupa gaya (force) dan perpindahan (displacement). Gaya diperoleh dari titik referensi yang terletak pada pusat alas (titik yang diberi keterangan "Lower" pada Gambar 2.5 sampai 2.7), sedangkan perpindahan diperoleh dari titik referensi yang terletak pada pusat stopper (titik yang diberi keterangan "Stopper" pada Gambar 2.5 sampai 2.7). Selanjutnya, untuk memperoleh nilai parameter indikator sesuai Bagian 2.1 (EA, PCF, dan MCF), variabel gaya dan perpindahan tersebut dihitung menggunakan persamaan (1) dan (2). 


\section{HASIL DAN PEMBAHASAN \\ Simulasi berdasarkan variasi} material ini menggunakan sabot jenis $2 \mathrm{lb}$ dengan kecepatan yang sama, yaitu 62 $\mathrm{m} / \mathrm{s}$. Kecepatan $62 \mathrm{~m} / \mathrm{s}$ didasarkan pada pengujian bird strike sesuai dengan CASR 23.775, yaitu pengujian pada pesawat komuter 19 penumpang ${ }^{[6]}$. Variasi material yang digunakan hanya pada selimut sabot, yaitu Alumunium Alloy 6061 T6, Steel 355, dan AISI 1340, sedangkan untuk filler I pengisi honeycomb masih sama, yaitu Aramid Ox-Core. Proses deformasi pada sabot $2 \mathrm{lb}$ yang berbahan Alumunium Alloy 6061-T6 ditunjukkan pada Gambar 3.1. Sabot $2 \mathrm{lb}$ yang berbahan Steel 355 ditunjukkan pada Gambar 3.2. Sabot $2 \mathrm{lb}$ yang berbahan AISI 1340 ditunjukkan pada Gambar 3.3.
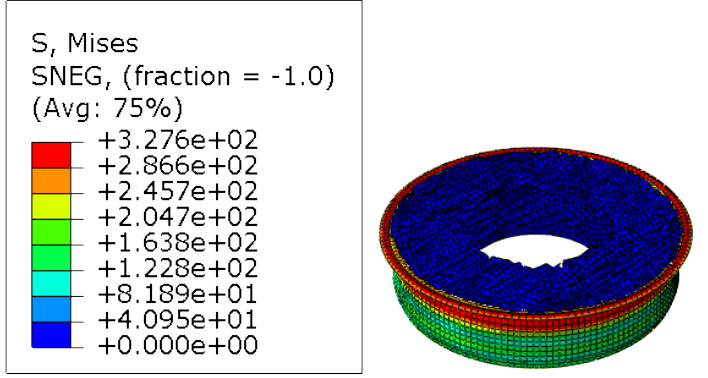

(a)

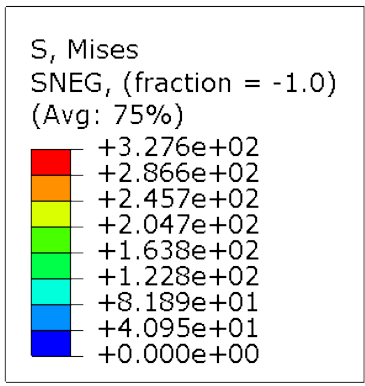

(b)

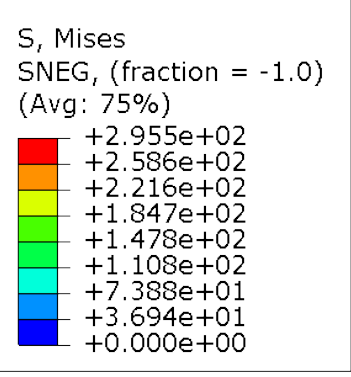

(c)

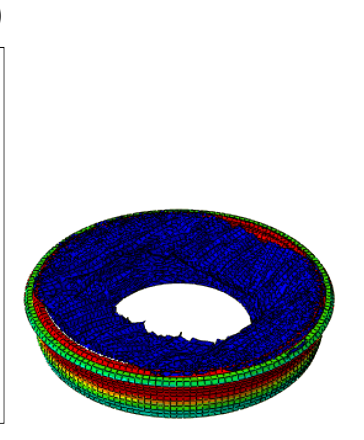

$$
\text { ) }
$$

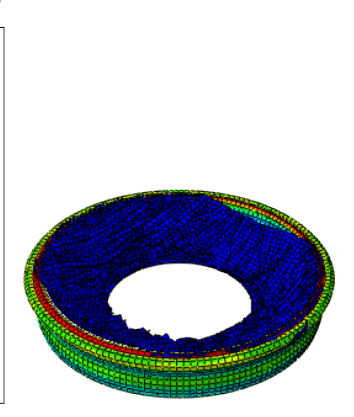

Gambar 3.1 Deformasi pada sabot $2 \mathrm{lb}$ dengan tinggi $84 \mathrm{~mm}$ berbahan AA6061-T6 ketika tumbukan pada waktu: (a) 0.6; 1.2; dan $1.78 \mathrm{~ms}$

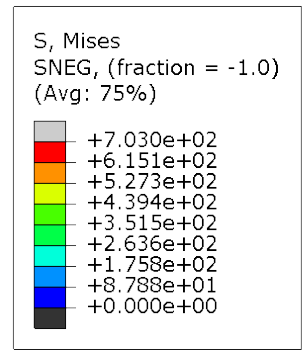

(a)
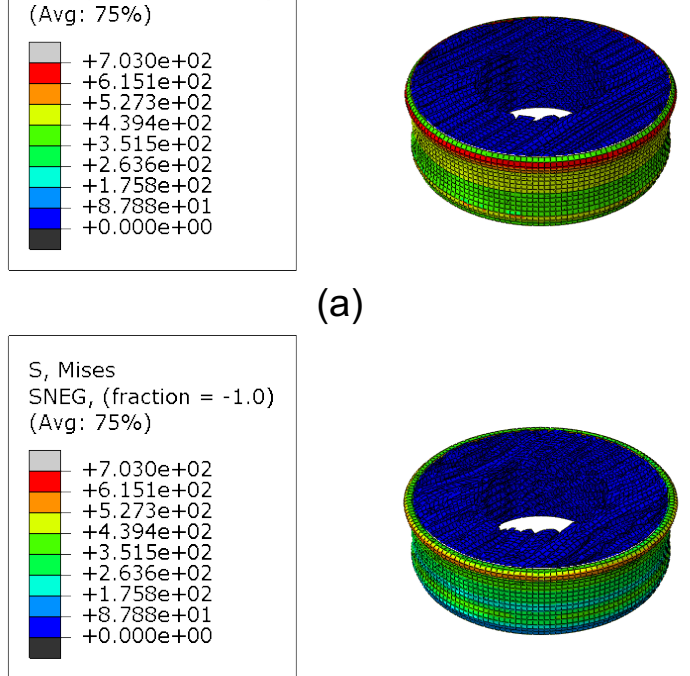

(b)
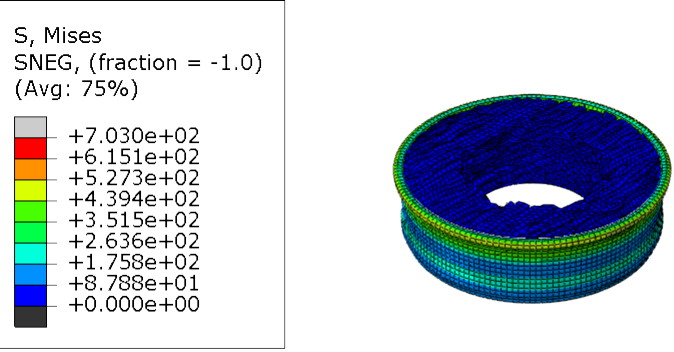

(c)

Gambar 3.2 Deformasi pada sabot $2 \mathrm{lb}$ dengan tinggi $84 \mathrm{~mm}$ berbahan Steel 355 , ketika tumbukan pada waktu: (a) 0.23 ; (b) 0.47; dan (c) $0.76 \mathrm{~ms}$
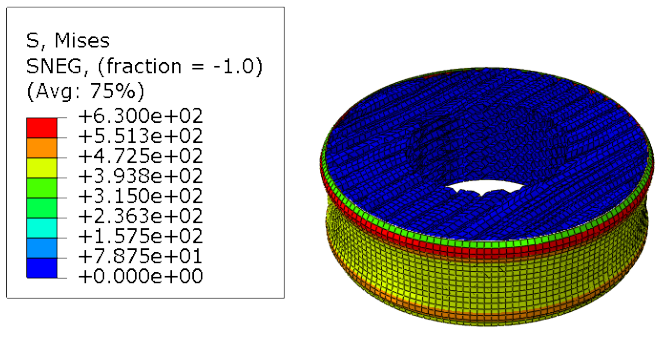

(a)
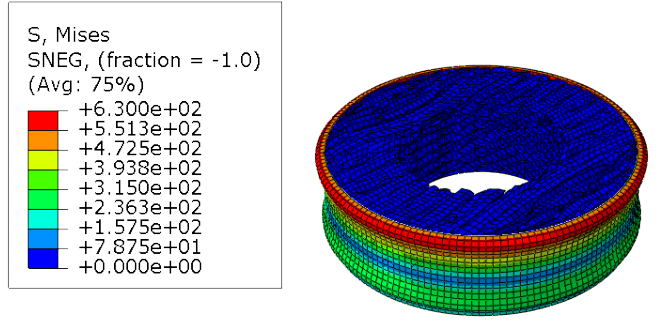

(b) 

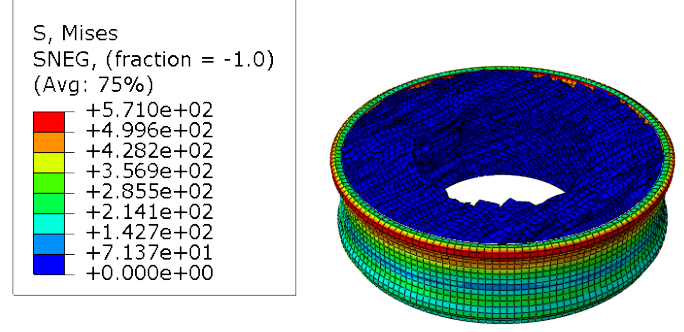

(c)

Gambar 3.3 Deformasi pada sabot $2 \mathrm{lb}$ dengan tinggi $84 \mathrm{~mm}$ berbahan AISI 1340, ketika tumbukan pada waktu: (a) 0.23 ; (b) 0.47 ; dan (c) $0.76 \mathrm{~ms}$

Pada hasil simulasi menghasilkan output, yaitu nilai force terhadap displacement yang ditampilkan dalam bentuk kurva instantaneous force seperti pada Gambar 3.4.

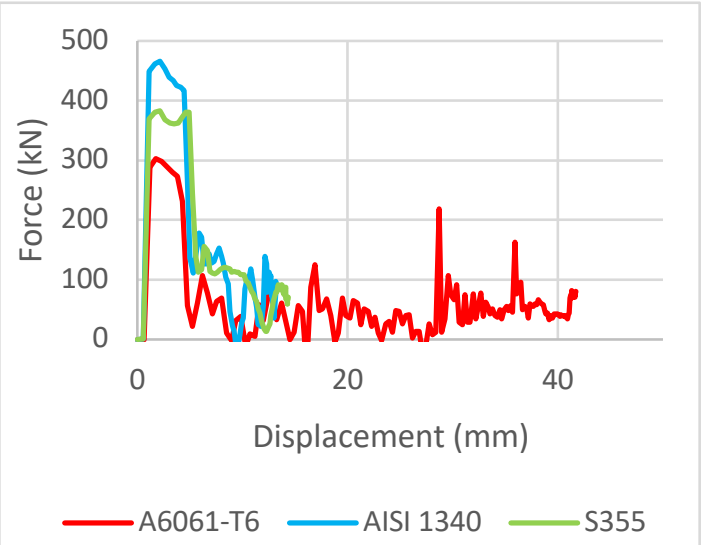

Gambar 3.4 Instantaneous Force dalam variasi material pada sabot $2 \mathrm{lb}$

Dari Gambar 3.4 dapat diperoleh beberapa variable seperti, EA (Energy Absorption), PCF (Peak Crushing Force), dan MCF (Mean Crushing Force). Setiap variabel tersebut diperoleh nilai dengan hasil seperti pada Tabel 3.1.

Tabel 3.1 Hasil analisis parameter berdasarkan variasi material pada sabot $2 \mathrm{lb}$

\begin{tabular}{|l|c|c|c|}
\hline \multirow{2}{*}{ Parameter } & \multicolumn{3}{|c|}{ Sabot 2lb } \\
\cline { 2 - 4 } & AA6061T6 & $\begin{array}{c}\text { Steel } \\
\mathbf{3 5 5}\end{array}$ & $\begin{array}{c}\text { AISI } \\
\mathbf{1 3 4 0}\end{array}$ \\
\hline EA (kJ) & 2.66 & 2.47 & 2.51 \\
\hline PCF (kN) & 303 & 383 & 466 \\
\hline MCF (kN) & 64.2 & 173 & 190 \\
\hline $\mathbf{t}$ (s) & 0.00157 & 0.00076 & 0.00071 \\
\hline
\end{tabular}

Dari Gambar 3.4, pola kurva menampilkan nilai puncak (peak crushing force) pada awal tumbukan disebabkan karena tumbukan awal, kemudian menurun dikarenakan energi yang berkurang. Luasan dibawah kurva tersebut merupakan energi yang diserap oleh sabot. Nilai EA, PCF, MCF, dan nilai stress/tegangan maksimum memiliki nilai yang berbedabeda karena pada setiap sabot ini memilki variasi material yang berbeda dengan kekuatan yang berbeda walaupun memiliki nilai pembebanan yang sama yaitu kecepatan tumbukan sebesar $62 \mathrm{~m} / \mathrm{s}$. Dengan beban yang sama, nila yield stress pada material alumunium lebih rendah dibandingkan steel. Dengan kata lain, ketika tegangan yang terjadi pada kedua material sama, maka akan menyebabkan nilai regangan yang berbeda, yaitu alumunium mengalami regangan lebih besar dari steel. Deformasi (regangan) plastis ditandai dengan tegangan yang melebihi nilai yield stress.

Oleh karena itu, pada variasi material menunjukkan bahwa EA dengan material AA 6061 T6 memiliki nilai paling besar, yaitu $2.66 \mathrm{~kJ}$. Hal ini disebabkan oleh kekuatan dari material ini tidak lebih kuat dari material Steel terutama pada material AISI 1340 yang memiliki nilai EA sebesar $2.51 \mathrm{~kJ}$ sehingga deformasi pada alumunium lebih tinggi ini disebabkan karena nilai yield stress. Untuk nilai PCF terbesar dimiliki oleh material AISI 1340, yaitu sebesar $466 \mathrm{kN}$ karena memiliki kekuatan yang sangat tinggi, maka dibutuhkan PCF yang besar untuk mengakibatkan struktur mengalami deformasi awal, sedangkan PCF terkecil dimiliki oleh material AA 6061 T6 sebesar $303 \mathrm{kN}$. Untuk MCF yang dialami oleh AA 6061 T6 lebih kecil karena kekuatan material tersebut lebih rendah, sedangkan MCF yang terbesar dimiliki oleh material AISI 1340.

Dari Tabel 3.1, nilai waktu tumbukan pada material A6061-T6 lebih besar (0.00157 s) karena kekuatan material tersebut tidak lebih kuat dari material S355 (0.00076 s) dan AISI 1340 (0.00071 s). Kekuatan tersebut ditinjau dari properti mekanik setiap material tersebut, misalnya yield strength yang merupakan batas maksimum suatu struktur mengalami deformasi elastis. Dengan kata lain, nilai yield strength material A6061-T6 (337.687 $\mathrm{MPa}$ ) lebih rendah dari S355 (355 MPa) dan AISI 1340 (434 MPa). 


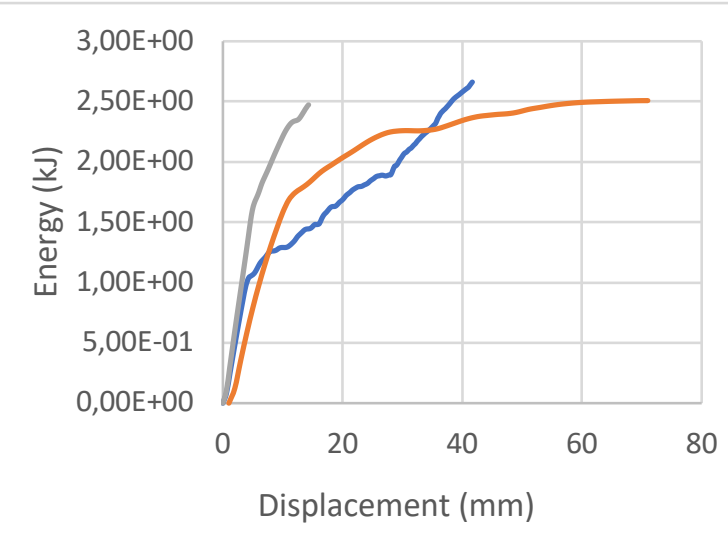

—AA 6061 T6

Gambar 3.5 Energy vs Displacement dalam variasi material pada sabot $2 \mathrm{lb}$

\section{KESIMPULAN}

Berdasarkan hasil dan pembahasan pada Bab IV, maka diperoleh beberapa kesimpulan sebagai berikut:

1. Waktu tumbukan yang paling singkat untuk memaksimalkan kecepatan pada burung (setelah keluar dari sabot) untuk variasi material dimiliki oleh sabot dengan material AISI 1340, yaitu $0.00071 \mathrm{~s}$.

2. EA pada material AA $6061 \mathrm{~T} 6$ memiliki nilai paling besar, yaitu $2.66 \mathrm{~kJ}$ karena kekuatan dari material ini tidak lebih kuat dari material Steel terutama pada material AISI 1340 yang memiliki nilai EA sebesar $2.51 \mathrm{~kJ}$ sehingga deformasi pada alumunium lebih tinggi.

3. PCF pada variasi material, PCF terbesar dimiliki oleh AISI 1340, yaitu senilai $466 \mathrm{kN}$ dikarenakan material ini memiliki kekuatan yang tinggi sehingga gaya untuk menghasilkan deformasi (buckling) pertama juga besar dibandingkan dengan material AA 6061 T6 yang bernilai 303 kN. Begitu juga MCF pada variasi material dengan alasan yang sama, yaitu kekuatan material steel, maka MCF terbesar dimiliki oleh AISI 1340, yaitu sebesar $190 \mathrm{kN}$ dibandingkan yang dimiliki oleh AA 6061 T6 sebesar 64.2 $\mathrm{kN}$.

4. Berdasarkan nilai waktu ( $\mathrm{t}$ ) paling singkat, PCF dan MCF paling tinggi, serta EA paling rendah, maka diperoleh material AISI 1340 sebagai material yang diinginkan karena paling berpengaruh terhadap peningkatan kecepatan burung setelah keluar dari sabot.

\section{DAFTAR PUSTAKA}

[1] Federal Aviation Administration, 2019, FAA Wildlife Strike Database, https://wildlife.faa.gov/home, diakses tanggal 26 Januari 2020.

[2] Lee SH, Saito $Y$, Sakai T., 2002, Microstructures and mechanical properties of 6061 aluminum alloy processed by accumulative rollbonding.; 325: 228-235.

[3] Agus Choiron., Djarot B., Anwari R Bintang., 2015. Analisis Penyerapan Energi dan Pola Deformasi Crash Box dengan variasi Sudut Tirus Dinding Crash Box pada Uji Simulasi Tabrakan Arah frontal. Jurnal Rekaya Mesin Vol. 6. No 1, 75-83.

[4] Heimbs, S., 2011, Bird Strike Simulations on Composite Aircraft Structures, European Aeronautic Defence and Space Company, Innovation Works, 81663 Munich, Germany.

[5] Nagel, Gregory, 2005, Impact and Energy Absorption of Straight and Tapered Rectangular Tubes, Queensland University of Technology.

[6] Keputusan Menteri Perhubungan tentang Civil Aviation Safety Regulation (CASR). Kepmenhub Nomor 25 tahun 2001. Part 23. Airworthiness Standards: Normal, Utility, Acrobatic, and Commuter Category Airplane. 